\title{
Perilaku Alturisme Karyawan (Studi Kasus pada Mandor Perkebunan Sawit Perseroan Terbatas (PT).Tribuana Mas Kabupaten Tapin) ${ }^{1}$
}

\author{
Asti Wulandari ${ }^{2}$ \\ Universitas Islam Negeri (UIN) Antasari, Banjarmasin
}

\begin{abstract}
Abstrak
One of the tasks of developing into adulthood is to work to meet the needs of his life. Technological advances, materialism, hedonism and the demands of the post-industrial society's needs make some people work brutally for what they want to be fulfilled. Even people are apathetic to the surrounding environment. Nevertheless, there are still a handful of employees who care about their environmental conditions by behaving altruism as happened in PT.Tribuana Mas (TBM). The purpose of this study is to describe employee altruism behavior and explore the factors that encourage employees to behave altruism. The results of the research on 3 employees of PT. Tribuana Mas plantation, Afdeling Juliet conducted qualitatively (nonparticipant observation and in-depth interview), altruism behavioral components are mostly the same, that is behaving helpfully, considering the rights and welfare of others, sharing and honesty. While the different components are seen from the behavior of donating $\mathcal{E}$ generosity and Cooperation. Components of altruism behavior reflected on the employees are also in accordance with the teachings of Islam, the namely charity with the foundation of god (ikhlas) and there are still nuanced humanity. It is influenced by various factors, both situational (external) and within (internal)
\end{abstract}

Kata kunci: Alturisme; Ketulusan; Karyawan.

\section{Pendahuluan}

Kerja adalah sebuah aktivitas yang sangat erat kaitannya dengan orang yang sudah memasuki usia produktif. Seseorang dikatakan produktif apabila laki-laki atau perempuan yang sudah memasuki kategori dewasa. Pada umumnya para psikolog menetapkan usia dewasa ketika seseorang telah memasuki usia 21 tahun. ${ }^{3}$

Tujuan manusia bekerja adalah untuk memenuhi kebutuhan. Kebutuhan itu bermacam-macam, berkembang dan berubah yang kerap kali tidak disadari oleh pelakunya.

\footnotetext{
1 Artikel ini merupakan hasil Skripisi pada tahun 2015 di Jurusan Psikologi Islam Fakultas Ushuluddin dan Humaniora Universitas Islam Negeri Antasari Banjarmasin.

${ }^{2}$ Korespondensi untuk tulisan ini ditujukan kepada email psychologiasty@gmail.com

${ }^{3}$ Desmita, Psikologi Perkembangan (Bandung: Remaja Rosdakarya, 2013). 234
} 
${ }^{4}$ Orang bekerja karena ada sesuatu yang hendak dicapainya dan berharap bahwa aktivitas yang dilakukan akan membawanya kepada suatu keadaan yang lebih memuaskan daripada keadaan sebelumnya. Ibnu Khaldun sebagai salah seorang sosiolog besar muslim menyatakan dalam muqaddimahnya bahwa sudah menjadi watak dasar dan bawaan manusia untuk senantiasa memenuhi kebutuhan hidupnya yang telah diciptakan Allah. Sebagaimana firman Allah swt. yang memerintahkan manusia bertebaran di muka bumi untuk mencari nafkah setelah melaksanakan salat, seperti dalam QS. al-Jumu'ah/62: 10:

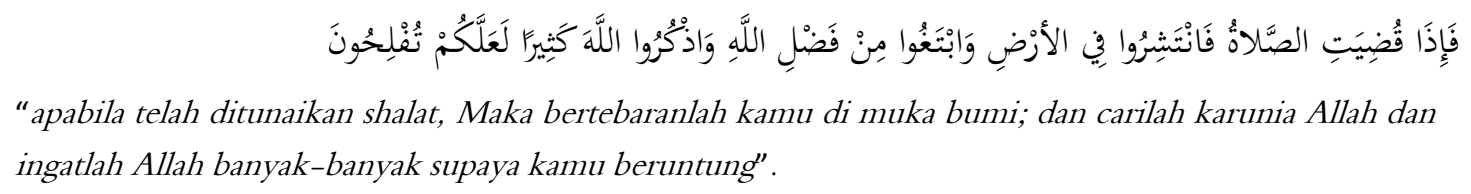

Dewasa ini, banyak motif yang mendorong orang untuk bekerja. Selain sebagai sumber penghasilan secara fisik, kerja juga merupakan aktivitas sosial yang di dalamnya terdapat hubungan sosial yang terorganisir dalam kehidupan masyarakat modern industrial yang lebih kompleks. Kerja merupakan suatu kesempatan untuk mengembangkan diri dan berbakti. Melalui pekerjaan kita berbuat sesuatu yang bernilai, bermanfaat bagi diri sendiri, anggota keluarga, masyarakat, bangsa dan negara, dan Tuhan pencipta. Selain itu pekerjaan juga dapat menumbuhkan harga diri. ${ }^{5}$ Dalam karya Ihya' ulum ad-Din, Al-Ghazali memandang bahwa sebagian di antara tugas-tugas sosial (fardhu kifayah) yang ditetapkan Allah adalah mengikuti arus perkembangan ekonomi. Untuk pertama kali pula, prinsip yang diakui oleh dunia lewat Perserikatan Bangsa-Bangsa (PBB) yaitu prinsip keseimbangan dalam pembangunan ekonomi dan pembangunan sosial yang sudah tercantum dalam UUD tahun $1945 .^{6}$

Kaitan antara bekerja dan interaksi sosial salah satunya terlihat dari perilaku tolong menolong. Namun, seiring kemajuan teknologi, materialisme dan tekanan pola hidup

\footnotetext{
${ }^{4}$ Pandji Anggora, Psikologi Kerja (Jakarta: Rineka Cipta, 2009). 11 lihat juga Syahrial Yusuf, Spiritual Enterpreneurship Quotien: Kiat Menjadi Pengusaha Dunia Bahagia, Akhirat Surga (Jakarta: Lentera Ilmu Cendikia, 2010). 67

${ }^{5}$ Karena seorang pengangguran lambat laun akan kehilangan harga dirinya sebagai seseorang yang belum mampu berbuat sesuatu Sunyoto Usman, Pembangunan Dan Pemberdayaan Masyarakat (Yogyakarta: Pustaka Pelajar, 2008). 87

${ }^{6}$ Muhammad Tholhah Hasan, Islam Dalam Perspektif Sosio Kultural (Jakarta: Lentabora Press, 2005). 160
} 
hedonisme membuat semakin berkembang pula aktivitas sehingga menguras pikiran dan perhatian individu yang pada akhirnya mengakibatkan berkurangnya rasa tolong menolong antar sesama karyawan. ${ }^{7}$ Selain itu, persaingan hidup di dunia kerja, bonus akhir tahun (insentif) yang tidak merata dan mobilitas kebutuhan hidup yang semakin mahal dan beragam juga membuat sebagian orang bersikap apatis terhadap lingkungan sekitarnya. Tidak jarang orang saling sikut untuk mendapatkan tingkat jabatan yang lebih tinggi di perusahannya sehingga kian mengikis perilaku altruisme di lingkungannya.

Dalam istilah psikologi, altruisme merupakan keprihatinan terhadap keadaan orang lain tanpa mengharapkan imbalan. Dalam pengertian filsafat dijelaskan altruisme berarti menyingkirkan hasrat-hasrat yang menyangkut diri dan hidup diabdikan pada kebaikan pihak lain. Dalam arti yang lebih luas, altruisme mencakup usaha untuk mencapai kebaikan bagi orang lain, baik karena dorongan kepentingan yang berpusat pada diri sendiri atau pada orang lain atau karena kewajiban tanpa pamrih. ${ }^{8}$

Di sisi lain, manusia dan agama tidak dapat dipisahkan. Kepentingan agama semakin diperlukan, minat terhadap agama meningkat pada abad ke-20 khususnya yang berkaitan dengan makna, tujuan hidup, etika, moral dan nilai. Religiusitas sangat penting dan berperan aktif demi terciptanya insan yang berjiwa altruisme. ${ }^{9}$ Pada tingkat personal, setiap individu juga menyadari bahwa dalam hati manusia ada rasa cinta terhadap dirinya sendiri maupun bagi orang lain. Salah satu bentuk ungkapan rasa cinta adalah dengan memberikan sesuatu kepada orang lain tanpa mengharapkan imbalan atau biasa disebut altruisme. ${ }^{10}$ Mencintai sesama saudaranya sebagaimana ia mencintai dirinya sendiri juga merupakan bagian dari keimanan seseorang, seperti sabda Rasulullah saw yang diriwayatkan dari Anas ra. ${ }^{11}$

\footnotetext{
${ }^{7}$ Henry Hazlitt, Dasar-Dasar Moralitas (Yogyakarta: Pustka Pelajar, 2003).120

${ }^{8}$ Anidal Hasjir, Kamus Istilah Psikologi (Jakarta: Progress, 2003). 7. Lihat juga Sudarsono, Kamus Filsafat Dan Psikologi (Jakarta: Rineka Cipta, 1993). 10

${ }_{9}^{9}$ Jalaluddin, Psikologi Agama (Jakarta: RajaGrafindo Persada, 1998). 20

${ }^{10}$ Fuad Nashori, Psikologi Sosial Islami (Jakarta: PT. Refika Aditama, 2008). 25

${ }^{11}$ Dari Anas ra:
}

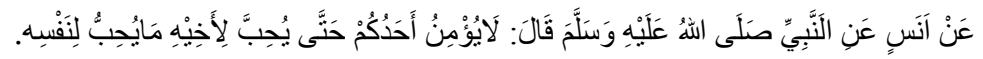

Artinya: "Dari Rasulullah saw. beliau bersabda: "tidaklah salah seorang dari kalian beriman sampai ia mencintai saudaranya sebagaimana ia mencintai dirinya sendiri." (HR. bukhari Muslim). LihatIbnu Hajar Al-Asqalani and Al Imam Al-Hafizah, Fathul Baari Syarah: Shahih Bukhari (Jakarta: Pustaka Azzam, 2008). 95 
Atas dasar kesamaan asal-usul dan kesamaan derajat di hadapan Allah swt, individu harus menyadari tanggung jawab yang telah ditentukan Allah. Tanggung jawab dapat diartikan berbagai macam, salah satu diantaranya adalah upaya untuk menciptakan kesejahteraan bersama dalam lingkungan suatu masyarakat. ${ }^{12}$ Seseorang yang tergolong mampu secara fisik, intelektual maupun harta maka dianjurkan untuk menolong orang yang tidak mampu. Sebaliknya orang yang tidak mampu namun berusaha sehingga dikatakan mampu, maka ia dianjurkan untuk memberi bantuan kepada orang yang tidak mampu atau dalam kesusahan. ${ }^{13}$ Seorang muslim hendaknya mengunjungi saudara muslim lainnya yang sakit, meringankan beban orang yang mendapat kesulitan, menciptakan rasa cinta kasih, persaudaraan dan solidaritas antara satu dan lainnya, ia juga hendaknya memberikan hak-hak orang sekelilingnya, seperti hak untuk mendapatkan kehidupan dan perlakuan yang layak. Islam menganjurkan terciptanya rasa kebersamaan dalam masyarakat dan saling membantu orang-orang yang sedang kesusahan, karena Allah menjanjikan pahala bagi orang-orang yang mau membantu sesama dengan $i k h l a s .{ }^{14}$

Perilaku meringankan beban orang di sekitar lingkungan kerjanya karena Allah, merupakan salah satu bentuk interaksi sosial yang konotasinya positif. Interaksi ini dapat dilakukan oleh individu dan individu, antara individu dan kelompok, atau antara kelompok. Interaksi sosial dapat dilakukan dalam semua agen dan organisasi sosial. Organisasi sosial yang tersedia di masyarakat dapat berupa lembaga pemerintah maupun swasta. Salah satu wadah yang akhir-akhir ini sangat menjamur di Kalimantan Selatan sebagai tempat orang bekerja adalah perusahaan yang bergerak di bidang perkebunan kelapa sawit. Perusahaan-perusahaan ini membuka lebar peluang kerja sehingga mengurangi jumlah pengangguran, mengurangi dampak urbanisasi dari desa ke kota karena terbatasnya peluang kerja, berkurangnya penyakit sosial (pencurian, premanisme, dan sebagainya) dan meningkatkan pendapatan masyarakat yang berdampak pada meningkatnya kesadaran atas pentingnya kesehatan, pendidikan dan pemenuhan kebutuhan lain.

\footnotetext{
${ }^{12}$ Muhammad Tholhah Hasan, Islam Dalam Perspektif Sosio Kultural. 161

${ }^{13}$ Lihat QS. al-Maidah/5: 02.

${ }^{14}$ Ibnu Hajar Al-Asqalani and Al Imam Al-Hafizah, Fathul Baari Syarah: Shahih Bukhari. Lihat juga QS Ali ‘Imran/3:134
} 
Tercatat hingga tahun 2013, perusahaan sawit legal yang terdata oleh Dinas Perkebunan Provinsi Kalimantan Selatan (Disbun) berjumlah 77 Perusahaan dengan luas wilayah 372.720 Ha (Hekta are) yang terdapat di sepuluh kabupaten (Kabupaten Banjar, Tanah Laut, Tanah Bumbu, Barito Kuala, Kota Baru, Tabalong, Hulu Sungai Utara, Tapin, Hulu sungai Selatan dan Balangan). ${ }^{15}$

Dari observasi yang peneliti lakukan di tiga perusahaan yang bergerak di bidang perkebunan sawit yang berbeda, ada satu perusahaan yang menarik untuk diteliti, yaitu PT.Tribuana Mas. Perusahaan ini berada di wilayah Kabupaten Tapin. Dalam sistem administrasi, penggajian bagi karyawan yang berasal dari luar Kalimantan menggunakan sistem banking atau Anjungan Tunai Mandiri (ATM) dan untuk sebagian karyawan pribumi (penduduk Kalimantan Selatan) masih secara langsung dan manual. Namun dalam perjalanannya hal ini ada kendala.

Hasil wawancara penulis di PT.Trubuana $\mathrm{Mas}^{16}$, setiap bulan masih ada saja gaji karyawan yang kurang dari jumlah harian kerja (HK) dan gaji lembur yang seharusnya diterimanya. Ada juga karyawan yang kerja full setiap hari mendapatkan gaji yang sama besar dengan karyawan lain yang sering tidak masuk kerja. Meski telah dilaporkan pada petugas bagian kerani (administrasi keuangan), namun tidak ada respon positif ataupun tindak lanjut dari permasalahan karyawan tersebut.

Pembagian beras yang tidak merata, bahkan ada saja karyawan yang tidak mendapat jatah beras sama sekali karena stok di gudang sudah habis kerap kali terjadi. Hal ini dikarenakan banyak oknum yang berbuat curang. Penulis pernah melihat saat para karyawan mengambil jatah beras, ironisnya ada saja karyawan yang lapor pada mandornya untuk mengambilkan jatah beras karyawan lain, namun tidak disampaikan jatah tersebut pada yang berhak.

Menurut penuturan salah seorang karyawan PT.Tribuana Mas, bahwa ada karyawan yang memberikan setengah dari jatah berasnya untuk karyawan lain yang tidak mendapat jatah beras dari perusahaan, seorang mandor yang selalu meluangkan waktu untuk mengajar ngaji anak-anak karyawan lain tanpa honor, seorang mandor yang membantu mandor lain yang belum bisa membuat laporan pertanggungjawaban kerja karyawan dan

\footnotetext{
${ }^{15}$ Dinas Perkebunan Prov Kalsel, "Statistik Disbun Provinsi Kalimantan Selatan," accessed March 2, 2015, http://disbun.kalselprov.go.id.

${ }^{16}$ PT. ialah singkatan dari "Perseroan Terbatas".
} 
ada mandor yang menutupi gaji karyawan bagian kastrasi yang kurang akibat kesalahan administrasi kantor tanpa memninta ganti rugi (uang kembali) pada pihak prusahaan atau manajernya. Menurut penuturan seorang mandor, ibadah menjadi motivasi tersendiri bagi seluruh gerak aktivitas kehidupannya sehingga meskipun secara kasat mata perilakunya cukup merugikan diri mereka, namun ada kepuasan diri dan rasa kebahagiaan yang ia rasakan. ${ }^{17}$

Jadi, di tengah kemajuan teknologi, gaya hidup yang materialistis dan tuntutan kebutuhan hidup yang dikenal dengan The post industrial society ${ }^{18}$ seyogyanya membuat perilaku altruisme kian terkikis. Bahkan orang menggunakan berbagai cara secara brutal agar sesuatu yang diinginkannya terpenuhi. Hal seperti ini juga terlihat di dunia kerja, terutama di PT.Tribuana Mas. Namun demikian, masih ada segelintir karyawan perusahaan yang masih mempertahankan perilaku altruisme dengan alasan bahwa ibadah atau agama merupakan pondasi utama dalam bekerja dan beramal. Karena meskipun secara kasat mata hal itu terlihat merugikan diri pelaku, tetapi pada hakikatnya ada rasa kepuasan dan kebahagiaan pada diri pelaku.

Berangkat dari permasalahan di atas, maka penulis tertarik meneliti tentang "Perilaku Altruisme Karyawan (Studi Kasus pada Mandor Perkebunan Sawit PT.Tribuana Mas)"

\section{Perilaku Altruisme dalam kacamata psikologi}

Kata altruisme berasal dari latin alter yang artinya "orang lain". Secara bahasa altruisme adalah perbuatan yang berorientasi pada kebaikan orang lain. Kata ini diangkat oleh Auguste Comte, filosof dan sosiolog Perancis pada abad 19. Dia membedakan antara perilaku menolong yang altruis dengan perilaku menolong yang egois. Menurutnya dalam memberikan pertolongan, manusia memiliki dua motif, yaitu altruis dan egois sebagai pendorongnya. Perilaku menolong egois bertujuan mencari manfaat dari orang yang ditolong. Sedangkan perilaku menolong altruis adalah perilaku menolong yang ditujukan semata-mata untuk kebaikan orang yang ditolong. Sedangkan altruisme menurut Aronson,

\footnotetext{
${ }^{17}$ F, mandor kastrasi Afdeling Juliet, wawancara pribadi, Tapin, 27-28 Desember 2014.

${ }^{18}$ The post industrial society adalah sebutan untuk masyarakat pasca industry dengan pendidikan dan pengetahuan sebagai sumber utama. Biasanya golongan kerah putih yang mendominasi dengan pusat perhatian produksi barang dan jasa (tidak lagi bersifat agraris), melek iptek, teoritis, gemar riset dan lebih mengkualitaskan istilah "ilmuwan".
} 
Wilson dan Akert adalah pertolongan yang diberikan secara murni, tulus, tanpa mengharap balasan (manfaat) apa pun untuk dirinya. ${ }^{19}$

Calrk mendefinisikan altruisme sebagai salah satu perilaku sosial yang didorong oleh motif yang sifatnya suka rela, ada ongkos yang harus dikeluarkan oleh penolong dan didorong oleh sesuatu selain harapan terhadap hadiah atau material. Jeremi Bentham berpandangan bahwa altruisme merupakan perilaku menolong yang menguntungkan orang lain tanpa harus menyediakan keuntungan langsung pada orang yang melakukan tindakan tersebut, karena konsep altruisme ada dibalik sirkuit otak yang mengalami seleksi alam. ${ }^{20}$

Dalam psikologi, menurut Mussen dan Eisenberg mengungkapkan bahwa komponen perilaku altruisme, yaitu cooperation (kerjasama), yaitu melakukan pekerjaan atau kegiatan secara bersama-sama, sharing (berbagi), yaitu kesediaan untuk ikut merasakan apa yang dirasakan orang lain, helping (menolong), yaitu membantu orang lain dengan cara meringankan beban fisik atau psikologis orang tersebut, donating (menyumbang), yaitu sifat senang memberi sesuatu pada orang lain, generosity (kedermawanan), yaitu perilaku suka beramal, suka memberi derma atau murah hati pada orang lain (kesediaan untuk memberikan barang miliknya kepada orang lain yang membutuhkan secara suka rela), honesty (kejujuran), yaitu kesediaan melakukan sesuatu seperti apa adanya dengan mengutamakan nilai kejujuran tanpa berbuat curang dan mempertimbangkan hak dan kesejahteraan orang lain..$^{21}$ Menurut Leed yang dikutip Taufik menjelaskan bahwa suatu tindakan menolong dapat dikatakan altruisme jika memenuhi beberapa kriteria, yaitu,

19 Taufik, Empati: Pendekatan Psikologi Sosial (Jakarta: RajaGrafindo Persada, 2012). 131

${ }^{20}$ Martin Seligman, Beyond Autentic Happiness: Menciptakan Kebahagiaan Paripurna Dengan Psikologi Positif (Bandung: Kaifa, 2013). 129

Dalam referensi lain, Baron dan Byrne mendefinisikan altruisme sebagai bentuk khusus dalam penyesuaian perilaku yang ditujukan demi kepentingan orang lain, biasanya merugikan diri sendiri dan termotivasi oleh hasrat untuk meningkatkan kesejahteraan orang lain agar lebih baik tanpa mengharapkan penghargaan. Sedangkan menurut Meyers orang yang altruis peduli dan mau membantu meskipun jika tidak ada keuntungan yang ditawarkan atau tidak ada harapan ia akan mengharapkan kembali sesuatu, namun secara tidak langsung altruisme merupakan motif untuk meningkatkan kesejahteraan orang lain tanpa sadar untuk kepentingan pribadi penolong. James Drever mendefinisikan altruisme sebagai pemikiran/keprihatinan terhadap kesejahteraan orang lain (tanpa mengharapkan imbalan). Henry Sitanggang mendefinisikan altruisme sebagai sikap kebersamaan atau sikap mementingkan perasaan orang lain. Sedangkan menurut Andi Mapiare, altruisme adalah salah satu dari empat jenis cinta yang ditandai dengan kecenderungan atau sikap rela dan perilaku mengorbankan diri (benda, waktu, bahkan keselamatan diri) untuk orang atau pihak yang dicintainya. Feldman mengartikan altruisme adalah perilaku yang bermanfaat bagi orang lain, tetapi jelas perilaku menolong memerlukan pengorbanan diri dari penolong.

${ }^{21}$ Tri Dayakisini and Hudainiah, Psikologi Sosial (Malang: UMM Press, 2008). 87 
memberikan manfaat bagi orang yang ditolong atau berorientasi untuk kebaikan orang yang akan ditolong, karena bisa jadi seseorang berniat menolong, namun pertolongan yang diberikan tidak disukai atau dianggap kurang baik oleh orang yang ditolong, pertolongan yang telah diberikan berproses dari empati atau simpati yang selanjutnya menimbulkan keinginan untuk menolong, sehingga tindakannya itu dilakukan bukan karena paksaan melainkan secara suka rela diinginkan oleh yang bersangkutan dan hasil akhir dari tindakan itu bukan untuk kepentingan diri sendiri. ${ }^{22}$ Dalam perkembangan berikutnya, Staub yang dikutip oleh Dayakisni, mengklasifikasikan indikator yang menjadi tindakan altruisme mmeliputi 3 hal, yaitu, tindakan itu berakhir pada dirinya dan tidak menuntut keuntungan pada pihak pelaku , dilakukan secara sukarela dan menghasilkan kebaikan. ${ }^{23}$

Berbagai teori muncul untuk memberikan pandangan mengenai altruisme sesuai dengan konstruk yang mereka kembangkan, diantaranya adalah:

1. Teori Behaviourisme-Altruisme. Teori ini menjelaskan perilaku altruisme dalam perspektif belajar sosial (social learning). B.F. Skinner beranggapan bahwa kita cenderung mengulangi atau memperkuat perilaku yang memiliki konsekuensi positif bagi diri kita. ${ }^{24}$ Seorang anak mengembangkan perilaku menolong melalui proses modeling (perilaku menolong bisa juga terbentuk karena pengalaman-pengalaman sebelumnya yang menyatakan bahwa perilaku menolong dapat memberikan keuntungan (positive reinforcement) atau terhindar dari hal-hal yang negatif (negative reinforcement). Jane Piliavin dalam Rahman mengatakan bahwa pengaruh pertimbangan untung rugi berpengaruh pada perilakunya..$^{25}$

2. Teori Pertukaran Sosial. Teori ini menyatakan bahwa tindakan seseorang dilakukan atas dasar untung dan rugi (bukan hanya material, namun juga immaterial seperti dukungan, penghargaan, keakraban, pelayanan, kasih sayang, perhatian dan sebagainya).

3. Teori Norma Sosial. Penjelasan teori ini ada kemiripan dengan pandangan teori conditioning, yaitu seseorang menolong karena diharuskan oleh norma-norma sosial di masyarakat. Terdapat tiga jenis norma sosial yang biasanya menjadi pedoman untuk

\footnotetext{
22 Taufik, Empati: Pendekatan Psikologi Sosial. 134

${ }^{23}$ Tri Dayakisini and Hudainiah, Psikologi Sosial. 87

${ }^{24}$ Feldman, R. S, Pengantar Psikolog, 10th ed., vol. 2 (Jakarta: Salemba Humanika, 2012). 228

${ }^{25}$ Agus Abdul Rahman, Psikologi Sosial: Integrasi Pengetahuan Wahyu Dan Pengetahuan Empirik (Jakarta: RajaGrafindo Persada, 2013). 225
} 
menjadi pedoman untuk memberikan pertolongan, yaitu: reciprocity Norm (norma timbal balik), responsibility norm (norma tanggung jawab sosial), yaitu seseorang menolong orang lain tanpa mengharapkan apapun darinya dan Equilibrium norm (norma keseimbangan), menurut norma ini seluruh alam semesta harus seimbang dan harmoni, Maka orang harus menjaga keseimbangan tersebut dengan saling menolong satu sama lain.

4. Teori Sosial-Kognitif. Menurut teori ini, perilaku prososial merupakan hasil dari pertimbangan kognitif. Menurut Latane dan Darley, seseorang akan melakukan perilaku prososial ataupun tidak merupakan hasil dari pertimbangan kognitif yang kadang terjadi di luar kesadaran kita, yang langkah-langkahhnya, yaitu: memperhatikan bahwa ada sesuatu yang salah, kemudian menginterpretasikan bahwa sesuatu yang salah itu membutuhkan pertolongan, maka akan muncul rasa bertanggung jawab secara personal untuk menolong. ${ }^{26}$

5. Teori Evolusi. Menurut teori ini seseorang menolong orang lain karena hendak mempertahankan jenisnya sendiri (bersifat genetik). Dalam upaya mempertahankan jenisnya terdapat tiga jenis pertolongan, yaitu: perlindungan orang-orang dekat (kerabat), timbal balik biologis dan orientasi seksual.

6. Hipotesis Empati-Altruisme. Menurut C.D Batson, altruisme berawal dari empati, pemahaman terhadap pikiran-pikiran dan perasaan-perasaan target sasaran akan menimbulkan keinginan untuk menolong target secara tulus atau yang dikenal dengan altruisme. $^{27}$ Mekanisme utama dari hipotesis empati-altruisme adalah reaksi emosi terhadap masalah orang lain. Menyaksikan orang lain yang sedang kesulitan (empathic concern) akan menimbulkan kesedihan atau kesukaran (sadness) pada diri orang yang melihatnya seperti kecewa dan khawatir (personal distress). Meskipun kesedihan dan kekhawatiran itu menimbulkan dorongan egoistik untuk mengurangi kekhawatiran diri sendiri (one's own distress), Batson juga mengatakan bahwa empathic corner menghasilkan motivasi altruistik (altruistic motivation) untuk mengurangi kekhawatiran orang lain (other person's distress). Proses mulai dari empathic concern hingga berkurangnya kekhawatiran orang lain maupun diri sendiri dapat digambarkan seperti gambar. 1

\footnotetext{
${ }^{26}$ Ibid. 225

27 Taufik, Empati: Pendekatan Psikologi Sosial. 138
} 


\section{Gambar 1}

Proses Terbentuknya Perilaku Altruisme Brdasarkan Teori Hipotesis-Altruisme

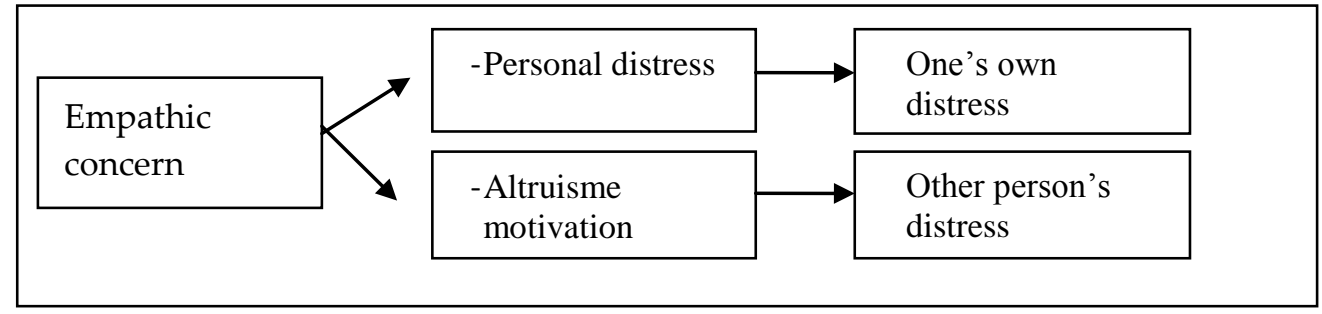

7. Teori Humanistik. Abraham Maslow (dikenal sebagai bapak humanistic) mengatakan bahwa perilaku altruisme merupakan manifestasi dari hirarki kebutuhan yang paling puncak, yaitu aktualisasi diri. Menurut Baihaqi, orang yang mengaktualisasikan diri memiliki tujuh sifat, yaitu: telah cukup memuaskan kebutuhan-kebutuhan yang lebih rendah secara teratur, terbebas dari psikosis, neorosis atau gangguan-gangguan patologis lain, dapat menjadi model pematangan dan kesehatan, memenuhi diri mereka sendiri dengan menggunakan kapasitas-kapasitas dan kualitas secara penuh, mengetahui "siapa aku", "untuk apa aku" dan "mau ke mana aku", usia telah matang dan aktualisasi diri sangat tergantung pada pengalaman-pengalaman masa kanak-kanak (yang masa anakanaknya merasa dicintai). ${ }^{28}$

Altruisme dapat terlihat dalam beberapa bentuk. Pearce, Bierhof dan Amato yang dikutip Rahman membagi situasi perilaku altruisme dalam tiga dimensi, yaitu:

\footnotetext{
${ }^{28}$ MIF Baihaqi, Psikologi Pertumbuhan: Kepribadian Sehat Untuk Mengembangkan Optimisme (Bandung: Remaja Rosdakarya, 2008). 208-209

Dalam referensi lain, perilaku altruisme dapat dilihat dari kriteria orang yang memiliki aktualisasi diri, yaitu: (1) Persepsi yang efesien tentang realitas: mereka menilai situasi secara akurat dan jujur serta memperhatikan kebohongan dan ketidak jujuran. (2) Penerimaan: diri, orang lain dan lingkungan. Mereka menerima kekurangan diri sendiri, juga kelemahan orang lain, serta pertentangan hidup. (3) Spontanitas: mereka tidak dapat dilarang, tidak peduli dengan apa yang difikirkan orang lain, aktif dan terlibat. (4) Orientasi tugas: mereka mempunyai misi, tugas, tujuan, atau masalah diluar diri pribadi yang harus diselesaikan. (5) Otonomi: mereka relatif bebas dari ikatan budaya, banyak akal, dan tidak tergantung pada orang lain atau pada otoritas luar. (6) Selalu menghargai kehidupan: mereka memiliki keluangan visi seorang anak, terus memperbaharui rasa menghargainya terhadap anugerah kehidupan. (7) Keterikatan dengan kemanusiaan: mereka mengidentifikasi secara dalam dengan kondisi manusia dan dengan orang lain secara umum. (8) Hubungan interpersonal yang dalam: mereka memiliki ikatan-ikatan yang dalam, mencintai, dengan sedikit orang terpilih. (9) Selera humor yang tidak menyinggung: mereka bisa menertawai diri sendiri dan kejadian-kejadian hidup yang menggelikan. (10) Pengalaman puncak (mistis atau oseanik): terjadi secara berkala lihat Lynn Wilcox, Psikologi Kepribadian: Analisis Seluk Beluk Kepribadian Manusia (Jogjakarta: IRCISoD, 2012). 289-290
} 
1. Berdasarkan setting sosialnya, perilaku altruisme bisa bersifat terencana dan formal atau spontan dan tidak formal (planned-formal versus spontaneous-informal).

2. Berdasarkan keadaan yang menerima pertolongan, perilaku ini bisa dikategorikan menjadi perilaku altruisme yang bersifat serius atau tidak serius (serious versus not serious).

3. Berdasarkan jenis pertolongannya, perilaku altruisme dapat bersifat mengerjakan langsung atau tidak langsung (doing direct versus giving indirect). Yaitu menunjuk pada apakah pertolongan itu diberikan langsung pada korban atau melalui pihak ketiga.

4. Berdasarkan kedekatan hubungan antara yang memberikan pertolongan dan yang menerima pertolongan (personal versus anonymous). ${ }^{29}$

Orang yang berperilaku altruisme tidak dapat terlepas dari faktor-faktor yang mendorongnya. Faktor pendorong perilaku altruisme menurut Sarlito W. Sarwono, dkk ada dua, yaitu faktor situasional dan faktor dari dalam dari.

1. Faktor Situasional:

a. Efek Bystander, yaitu kecenderungan individu yang mengamati suatu keadaan darurat untuk menolong ataupun tidak ketika ada pertimbangan ada dan tidaknya orang lain ketika peristiwa terjadi. Para psikolog sosial menyimpulkan bahwa ketika hanya kita sendiri yang menyaksikan peristiwa darurat seperti kecelakaan, maka kecenderungan kita berperilaku altruisme mencapai 75\%.30 Efek bystander terjadi karena tiga hal, yaitu: social influence (pengaruh sosial), audience inhibition (hambatan penonton) dan diffusion of responsibility (penyebaran tanggung jawab). ${ }^{31}$

b. Daya Tarik, atribusi terhadap korban dan adanya model (modeling).

${ }_{29}$ Dalam referensi lain, Mc. Guire berpendapat bahwa perilaku altruisme terbagi menjadi empat bentuk, yaitu: Casual helping (pertolongan yang sifatnya umum), Substantial personal helping (pertolongan yang membutuhkan usaha yang dapat menguntungkan orang lain), Emotional helping (pertolongan dengan memberikan dukungan emosional/sosial) dan Emergency helping (pertolongan bersifat darurat). Agus Abdul Rahman, Psikologi Sosial: Integrasi Pengetahuan Wahyu Dan Pengetahuan Empirik. 222-223

${ }^{30}$ Lura L King, Psikologi Umum: Sebuah Pandangan Apresiatif (Jakarta: Salemba Humanika, 2010). 191192

${ }^{31}$ Sarlito W. Sarwono and Eko A. Meinarno, Psikologi Sosial (Jakarta: Salemba Humanika, 2009). 132 


\section{Faktor dari Dalam Diri}

a. Mood (suasana hati), Synder \& Lopez yang senada dengan Rosenhan, Moore dan Underwood menyimpulkan dalam penelitiannya bahwa orang-orang yang bahagia lebih mungkin menolong. ${ }^{32}$

b. Sifat, menurut Karremans dalam Warsono terdapat hubungan antara karakteristik seseorang dengan kecenderungan menolong. Orang yang mempunyai sifat pemaaf (forgiveness) akan mempunyai kecenderungan mudah menolong. ${ }^{33}$

c. Kesamaan, Kesamaan erat kaitannya dengan menyukai dan menyukai erat kaitannya dengan membantu. Menurut Miller yang dikutip oleh Meyers, kita akan lebih empati dan cenderung membantu mereka yang sama atau mirip dengan kita (bisa tampilan fisik maupun kepercayaan). ${ }^{34}$

${ }^{32}$ Robert Stephen Feldman, Social Psychology: Theories, Research and Aplications (New York: McGRAWHILL Book Company, 1985). 247

${ }^{33}$ Sarlito W. Sarwono and Eko A. Meinarno, Psikologi Sosial. 131-138

Dalam referensi lain, Bierhoff, Klein dan Kramp mengemukakan faktor-faktir dalam diri yang menyusun kepribadian altruisme yaitu adanya:

1. Empati. Emosi sosial penting yang terlibat dalam altruisme adalah empati. Empati terjadi ketika kita merasa menyatu dengan keadaan emosional orang lain. Ketika kita merasa empati terhadap kesusahan orang lain, kita akan tergugah (muncul kepedulian tulus kepada orang lain). Empati dapat menghasilkan perilaku altruisme bahkan terhadap anggota kelompok yang menjadi saingan kita atau ketika kita meyakini tidak akan pernah ada orang yang mendengar tindakan baik kita.

2. Mempercayai Keadilan Dunia (Just world). Yaitu keyakinan bahwa dalam jangka panjang yang salah akan dihukum dan yang baik akan dapat ganjaran. Orang yang keyakinannya kuat terhadap keadilan dunia akan termotivasi untuk mencoba memperbaiki keadaan ketika mereka melihat orang yang tidak bersalah menderita. Maka tanpa pikir panjang mereka segera bertindak memberi pertolongan jika ada orang dalam kondisi sulit.

3. Tanggungjawab Sosial. Mereka yang paling menolong mengekspresikan kepercayaan bahwa setiap orang bertanggung jawab untuk melakukan yang terbaik untuk menolong orang yang membutuhkan.

4. Internal Locus of control. Adanya kepercayaan individu bahwa ia dapat memilih untuk bertingkah laku dalam cara yang memaksimalkan hasil akhir yang baik dan meminimalkan yang buruk. Mereka yang menolong memiliki locus of control internal yang tinggi. Selain itu, orang yang altruisme biasanya memiliki egosentrisme rendah. Mereka yang berperilaku altruisme tidak bermaksud untuk menjadi egosentris. Lihat Robert A. Baron and Byrne Donn, Psikologi Sosial Jilid 1 (Jakarta: PT Gelora Aksara Pratama, 2004). 116-117

${ }^{34}$ David G Myer, Psikologi Sosial (Jakarta: Salemba Humanika, 2012). 220 
d. Pola Asuh, pola asuh yang bersifat demokratis secara signifikan memfasilitasi adanya kecenderungan anak untuk tumbuh menjadi orang yang altruis, yaitu adanya modeling dari orang tua. ${ }^{35}$

e. Harapan (expectation), prinsip ini merupakan prediksi pribadi. Harapan berasal dari berbagai sumber, antara lain pengalaman masa lalu, informasi yang diperoleh dari orang lain dan stereotype. Terkadang harapan menjadi self-fulfilling prophecies, suatu situasi di mana harapan kita tentang orang lain tidak hanya membentuk perilaku sendiri, tetapi juga menyebabkan orang tersebut untuk berperilaku dengan cara-cara yang mengonfirmasi kepercayaan awal kita tentangnya. ${ }^{36}$

f. Gender dan Kepercayaan Religius. Dalam penelitian Mauren Crowley (1986) yang dikutip oleh Meyers, terlihat perbandingan $90 \%$ orang lebih menolong perempuan dan anak-anak dibandingkan memberikan pertolongan pada laki-laki. Penelitian ini dilakukan sebanyak 172 kali dan melibatkan 50.000 orang laki-laki dan perempuan. Menurut Frank Emerson (1953) yang dikutip oleh Meyers, agama adalah pusat dari kedermawanan. Kepercayaan religius memprediksikan altruisme jangka panjang, sebagaimana yang direfleksikan dalam kegiatan sukarela dan kontribusi amal. ${ }^{37}$

\section{Metode}

1. Lokasi penelitian

PT.Tribuana Mas (TBM) yang terletak di Desa Sungai Salai KM. 25 kecamatan Candi Laras Utara Kabupaten Tapin. Jarak tempuh dari pusat kecamatan \pm 13 KM. Jarak tempuh dari Ibu kota provinsi ke Rantau adalah 113 KM. Jarak tempuh menuju PT.TBM melalui jalur air, dari tepi Sungai Barito yang berada di Kecamatan Lepasan/Balukung (Batola) adalah 3 KM. PT. TBM diapit oleh beberapa perusahaan sekitarnya, yaitu di sebelah utara diapit oleh PT. DKCP, bagian timur diapit PT.SAHUYA, bagian tenggara diapit oleh PT.PAS dan bagian barat diapit oleh PT.TAL. 38

\footnotetext{
35 Aliah B. Purwakania Hasan, Psikologi Perkembangan Islami: Menyingkap Rentang Kehidupan Manusia Dari Kelahiran Hingga Pascakematian (Jakarta: RajaGrafindo Persada, 2006). 263

${ }^{36}$ Elis Anisah Fitriah, Psikologi Sosial Terapan (Bandung: Remaja Rosdakarya, 2014). 12

${ }^{37}$ David G Myer, Psikologi Sosial. 229

${ }^{38}$ Data diperoleh dari peta Arsip PT. ТвM
} 
2. Subjek penelitian

Subjek penelitian yang dilakukan di perkebunan sawit PT.Tribuana Mas ini berjumlah 3 orang laki-laki. Adapun karakteristik subjek dalam penelitian ini adalah karyawan yang bekerja di Perusahaan PT.Tribuana Mas, Afdeling Juliet dan tinggal di Mes karyawan. Ketiga subjek penelitian memiliki latar belakang berbeda-beda, baik dari segi usia, latar belakang keluarga, posisi jabatan, jumlah anak, dan lama bekerja di perusahaan tersebut. Selengkapnya identitas subjek dapat dipaparkan dalam tabel berikut ini

Tabel 1

Identitas Subjek Penelitian

\begin{tabular}{|c|c|c|c|c|c|c|}
\hline No. & $\begin{array}{l}\text { Subjek } \\
\text { (Inisial) }\end{array}$ & $\begin{array}{c}\text { Usia } \\
\text { (Tahun ) }\end{array}$ & $\begin{array}{c}\text { Latar belakang } \\
\text { keluarga }\end{array}$ & Posisi jabatan & Lama bekerja & $\begin{array}{c}\text { Jumlah } \\
\text { anak }\end{array}$ \\
\hline 1 & $A B$ & 22 & Penggalam 39 & Mandor I & \pm 3 tahun & 2 \\
\hline 2 & PA & 23 & Petani & $\begin{array}{l}\text { Mandor } \\
\text { Kastrasi }\end{array}$ & \pm 1 tahun & 1 \\
\hline 3 & AW & 19 & Wiraswasta & $\begin{array}{l}\text { Mandor } \\
\text { semprot }\end{array}$ & \pm 1 tahun & - \\
\hline
\end{tabular}

3. Jenis Penelitian dan metode pengumpulan data

Penelitian ini berupa penelitian lapangan (field research) menggunakan tinjauan Psikologi Islam dengan pendekatan studi kasus (case study) dalam deskriptif kualitatif dengan cara penggalian data dari lapangan secara mendalam, luas dan menyeluruh. Pengumpulan data dalam penelitian ini dilakukan dengan observasi dan wawancara. Dalam penelitian ini penulis menggunakan observasi nonpartisipan. Adapun data ovservasi yang diperoleh dalam bentuk kesan umum (kondisi fisik dan penampilan subjek), aktivitas sehari-hari subjek, lingkungan tempat tinggal subjek, perilaku subjek dalam berinteraksi dengan lingkungan sekitar, perilaku subjek saat di tempat kerja, respon subjek terhadap keadaan lingkungan sekitar dan bentuk-bentuk perilaku altruisme yang dilakukan subjek. Wawancara yang digunakan dalam penelitian ini wawancara mendalam/ wawancara semi terstruktur. Jenis wawancara ini dipilih agar didapatkan data yang lengkap dan bertujuan untuk menggali data sebanyak mungkin dari responden hasilnya berupa identitas (latar belakang) subjek, kondisi keluarga subjek, hubungan subjek dengan

\footnotetext{
${ }^{39}$ Penggalam ialah istilah yang duganakan pada profesi orang yang pekerjaannya "menebang pohon galam di hutan dengan diameter tertentu, kemudian menjual batang/pohon tersebut pada pemasok"
} 
anggota keluarganya, interaksi subjek dengan lingkungan tempat tinggal subjek, interaksi subjek dengan rekan kerjanya, permasalahan yang terjadi di lingkungan sekitar subjek, faktor-faktor yang menyebabkan subjek berperilaku altruisme (eksternal dan internal), serta pandangan subjek tentang keberadaan dirinya di lingkungan sekitar subjek.

\section{Hasil dan Diskusi}

Perilaku altruism karyawan PT. Tribuana Mas dan faktor-faktor yang mempengaruhinya

Perilaku altruisme dapat diartikan sebagai perilaku menolong orang lain yang merupakan bagian dari perilaku prososial. Dengan kata lain perilaku altruisme adalah tindakan yang dilakukan dengan tujuan untuk menolong dan memberikan manfaat secara positif bagi orang lain. Tindakan tersebut dilakukan secara suka rela tanpa mengharap imbalan pada orang yang ditolong. ${ }^{40}$ Menurut Mussen dan Eisenberg, perilaku altruisme memiliki tujuh komponen, yaitu sharing (membagi), cooperative (kerjasama), donating (menyumbang), helping (menolong), honesty (jujur), generosity (kedermawanan) dan mempertimbangkan hak dan kesejahteraan orang lain. ${ }^{41}$

\section{Tabel 2}

Gambaran Perilaku Altruisme Karyawan Perkebunan Sawit PT.Tribuana Mas

\begin{tabular}{|c|c|c|c|c|}
\hline No & $\begin{array}{l}\text { Komponen } \\
\text { Alturisme }\end{array}$ & $\begin{array}{l}\text { Subjek I } \\
\text { (AB) }\end{array}$ & $\begin{array}{l}\text { Subjek II } \\
\text { (PA) }\end{array}$ & $\begin{array}{l}\text { Subjek III } \\
\text { (AW) }\end{array}$ \\
\hline 1 & $\begin{array}{l}\text { Helping } \\
\text { (menolong) }\end{array}$ & $\begin{array}{l}\text { - terjun lapangan } \\
\text { langsung } \\
\text { membantu } \\
\text { karyawan yang } \\
\text { tidak paham } \\
\text { instruksi }\end{array}$ & $\begin{array}{l}\text { - } \text { membantu } \\
\text { tetangga } \\
\text { mentransfer uang } \\
\text { atau mengambil } \\
\text { paket, membantu } \\
\text { membelikan } \\
\text { barang (hp, spear } \\
\text { path kendaraan) } \\
\text { tanpa } \\
\text { memanipulasi } \\
\text { harga }\end{array}$ & $\begin{array}{l}\text { - } \text { mengambil air } \\
\text { bersih ke } 13 \\
\text { - } \text { ringan tangan } \\
\text { membelikan } \\
\text { titipan tetangga }\end{array}$ \\
\hline
\end{tabular}

\footnotetext{
${ }^{40}$ David G Myer, Psikologi Sosial. 187. Lihat juga Taufik, Empati: Pendekatan Psikologi Sosial. 134

${ }^{41}$ Tri Dayakisini and Hudainiah, Psikologi Sosial. 87
} 
2 Mempertimban gkan hak \& kesejahteraan orang lain

$3 \quad$ Sharing (berbagi)

4

Donating \&generosity

5 Honesty (jujur)

6 Cooperation (kerjasama)
- mengusahakan status karyawan PKWT menjadi karyawan tetap

- merekomendasika n karyawan potensial untuk naik golongan atau jabatan

- berbagi pengalaman dan pengetahuan tentang penguasaan lahan dan tes kenaikan jabatan

- menutupi kekurangan gaji karyawan bawahannya

- Kerja sesuai prosedur waktu yang telah ditentukan
- merekomendasik an karyawan PKWT menjadi karyawan tetap
- tegas dalam menetapkan kebijakan pada karyawan bawahannya
- mengajar ngaji anak-anak

- berbagi keceriaan

- menjadi tempat curhat rekan kerja/temantemannya
- memberi sebagian /seluruh jatah beras subjek pada karyawannya

- Disiplin dan waktu kerja sesuai prosedur

- Jujur ketika diamanahi tetangga barang titipan.
- Jujur dan tegas baik pada atasan atau bawahan jika menurutnya ada hal yang tidak sesuai.

- Subjek bersama beberapa teman mengambil air bersih untuk para tetangga AFD.OJ

Berdasarkan data yang didapat, ketiga subjek sama-sama memiliki komponen helping (menolong). Komponen ini terlihat pada salah satu subjek yang suka terjun ke lahan langsung untuk membantu karyawan bawahannya yang mengalami kesulitan dalam penguasaan teknik kerja lapangan. Pada subjek lain komponen ini terlihat dari perilakunya yang tidak pernah menolak membantu tetangga yang menitip suatu barang, mentranferkan uang, mengambilkan paket pos dan lainnya saat ia pulang kampung (turunan). Sedangkan pada subjek lainnya terlihat pada kesediaannya untuk mengemudikan mobil ketika 
mengambil air bersih ke 13, ringan tangan ketika keberangkatannya ke 13 ada tetangga yang menitip belikan sembako atau keperluan lain di warung.

Komponen mempertimbangkan hak dan kesejahteraan orang lain berdasarkan data dari ketiga subjek tampak ketika ada dua subjek yang sama-sama mengusahakan perubahan status karyawan bawahannya dari karyawan kontrak menjadi karyawan SKU dan merekomendasikan karyawannya yang kompeten untuk naik jabatan/menjadi mandor. Sedangkan subjek lain tegas dalam memimpin karyawan bawahannya agar karyawannya tidak ada yang dirugikan dengan manajemen waktu kerja yang disiplin dan menggunakan fasilitas kerja yang sesuai (sarana dan prasarana).

Komponen sharing (berbagi) berdasarkan data yang didapat dari ketiga subjek terlihat dalam bentuk yang berbeda-beda. Pada subjek satu, sharing dilakukan dalam bentuk berbagi pengalaman dan pengetahuan baik mengenai teknik penguasaan lahan maupun menghadapi tes kenaikan jabatan/golongan bagi rekan kerja dan karyawan bawahannya. Subjek dua berbagi ilmu dan pengetahuan dengan mengajar mengaji iqro dan tata cara sholat anak-anak yang berada di lingkungan Afdeling Juliet. Sedangkan subjek tiga selalu sharing/berbagi keceriaan dan kebahagiaan pada lingkungan sekitarnya. Kepribadiannya yang ceria dan supel dalam bergaul, membuat AW sering dijadikan tempat curhat oleh rekan kerjanya. Subjek AW juga menjadi mediator rekan kerjanya yang salah paham atau berselisih.

Komponen donating dan generosity berdasarkan data di atas terlihat pada dua subjek dan tidak terlihat pada salah satu subjek. Perilaku ini terlihat dari kepedulian subjek pada karyawan bawahannya yang mendapat gaji kurang dari yang seharusnnya sehingga ia menutupi gaji karyawannya tersebut dengan sedikit dari uang gajinya, memberikan sebagian atau seluruh jatah berasnya bulan itu pada karyawannya yang tidak mendapat jatah beras atau mendapat jatah beras kurang dari seharusnya.

Komponen honesty berdasarkan data ketiga subjek terlihat dalam bentuk yang berbeda. Dua subjek tepat waktu/disiplin dalam bekerja (tidak mengurangi jam kerja). Sedangkan subjek lain tegas (baik pada atasan ataupun bawahan jika ada hal yang menurutnya tidak sesuai). Hal ini terlihat dari perilaku subjek yang berani berbicara/berpendapat saat breafing dan dimarahi asisten karena ada pekerjaan yang terlihat tidak sesuai. Komponen cooperation berdasarkan data di atas, terlihat tampak pada subjek 
yang selalu bersedia meluangkan waktu untuk mengambil air bersih ke 13 bersama beberapa teman.

Berdasarkan paparan data tersebut, ketiga subjek memenuhi kriteria perilaku altruisme baik secara kontemporer ataupun dari sudut pandangan Islam, yaitu semua perilaku memberikan manfaat bagi orang yang ditolong dan sampai saat ini rekan kerja dan karyawan bawahan ketiga subjek tidak ada yang tidak menerima dengan baik. Perilaku ketiga subjek juga memenuhi indikator perilaku altruisme, yaitu perilaku yang ketiga subjek lakukan tidak menuntut keuntungan pada pihak pelaku, tindakan dilakukan secara suka rela dan tindakan ketiga subjek menghasilkan kebaikan.

Dalam Islam, hampir segala aspek kehidupan terkait dengan nilai-nilai Ilahiyyah, termasuk perilaku altruisme. Perilaku altruisme yang merupakan bagian dari tindakan prososial merupakan suatu perilaku yang dimuliakan dalam Islam. Menurut Botson dan Clark, Islam menganggap penting motif yang melatarbelakangi perilaku prososial, yaitu meluruskan niat ketika seseorang bersedekah. Meluruskan niat ini dalam Islam dikenal dengan kata ikhlas. ${ }^{42}$

Senada dengan itu, perilaku dua subjek memenuhi kriteria ikhlas. Kedua subjek memenuhi kriteria altruisme yang dikemukakan Mujib, yaitu adanya al-khatir (gerak dan lintasan batin melakukan perilaku baik), azzam (membulatkan tekad untuk bertindak), niat (kesadaran komitmen dan ilahiyyah yang memotivasi) kemudian af'al (bertindak). Pada subjek satu tergambar dari pernyataan subjek yang mengatakan bahwa segala penilaian yang baik dan buruk itu adalah rezeki dari Allah. Ia hanya berusaha berbuat baik dan mengharapkan hasil akhir yang baik berupa kemudahan dan rezeki yang berlebih dari Allah. Hal ini menurut Dzun Nun al-Misry, subjek ini termasuk ciri-ciri orang ikhlas. ${ }^{43}$ Berdasarkan data yang didapat, subjek satu adalah orang yang sabar dan mudah mengontrol emosi (pemaaf), Menurut Muhammad bin Shalih al-Munajjih hal ini merupakan salah satu ciri orang ikhlas yaitu sabar (tidak mengeluh dalam mengerjakan amal baik). ${ }^{44}$ Sedangkan Pada subjek dua tergambar dari pernyataan subjek yang mengatakan bahwa

\footnotetext{
${ }^{42}$ Agus Abdul Rahman, Psikologi Sosial: Integrasi Pengetahuan Wahyu Dan Pengetahuan Empirik. 222. Lihat juga Abu Fajar Al-Qalami, Ringkasan Ihya'Ulumiddin, 2003. 397

${ }^{43}$ Syukri Amin, Tasawuf Kontekstual Solusi Problem Manusia Modern (Yogyakarta: Pustaka Pelajar, 2003). 120

${ }^{44}$ Muhammad, , Takwa, Wara', h. 52.
} 
subjek merasa damai dan tenang pikirannya ketika tetangga yang ia anggap sebagai saudaranya dalam keadaan sejahtera, ia pun dapat mengamalkan ajaran agama dengan menjadi sebaik-baik manusia yaitu orang yang bermanfaat bagi sesama. Ia juga mengembalikan segala penilaian manusia pada Allah. Ia cuek pada penilaian orang yang tidak baik terhadap solusi yang ia ambil karena ia menyadari tidak ada yang sempurna di dunia ini. Menurut Abu Thalib al-Makki subjek ini memiliki ciri-ciri orang ikhlas yaitu tidak pedulinya jiwa terhadap pujian dan celaan (menganggap sama antara pujian dan celaan) dan ia berusaha memurnikan amal dari berbagai penyakit hati dan noda seperti riya' ${ }^{45}$

Adapun subjek ketiga yang sesuai dengan kriteria altruisme dalam Islam terlihat ketika ia selalu bersedia menjadi tempat curhat (curahan hati/berkeluh kesah) dan mendamaikan rekan kerjanya yang sedang salah paham bagi rekan kerja yang mempercayainya karena ia mengamalkan ajaran agama yaitu dermawan. Sebagaimana pendapat Ibnu Qayyim yang mengacu pada sabda Rasulullah bahwa mendamaikan orang yang sedang berselisih juga termasuk sedekah. ${ }^{46}$ Sedangkan ketegasan subjek dalam memutuskan kebijakan pada karyawan bawahannya dilakukan untuk alasan lain (bukan aspek Ilahiyyah), sehingga perilakunya mengindikasikan bahwa perbuatannya tidak termasuk kriteria ikhlas, tetapi baru mencapai tingkat tulus. ${ }^{47}$

Menurut Adul Mujib dan Jusuf Mudzakir, salah satu tingkatan ikhlas ialah beramal berdasarkan ilmu dan hukum-hukum-Nya. Artinya seseorang yang beramal harus ada dasar ilmunya, menyesuaikan dengan keadaan dirinya, dan memperhatikan pahala dan surga di kemudian hari. ${ }^{48} \mathrm{Hal}$ ini terlihat pada salah satu subjek yang donating \& generosity sesuai dengan kemampuannya. Ia mengakui bahwa ia tidak bisa menutupi gaji karyawan bawahannya karena secara finansial ia memiliki tanggungan anak yang masih memerlukan banyak biaya. Subjek lain mampu donating \& generosity dalam bentuk lain sesuai kemampuannya. Dengan demikian, berdasarkan pendapat Imam Al-Gazali yang dikutip oleh Muhbib Abdul Wahab, perilaku altruisme kedua subjek termasuk tingkatan ikhlas

\footnotetext{
${ }^{45}$ Abu Thalib Al-Makky, Quantum Qalbu: Nutrisi Untuk Hati, h. 277.

${ }^{46}$ Ibnu Qayyim Al-Jauziyah, Madarijus Salikin (Pendakian Menuju Allah), Penjabaran Kongkrit Iyyaka Na'budu Wa Iyyaka Nasta'in, Terj (Jakarta: Pustaka Al-Kautar, 2005). 252

${ }^{47}$ Cliff Goddard, "Sabar, Ikhlas, Setia-patient, Sincere, Loyal? Contrastive Semantics of Some 'virtues' in Malay and English," Journal of Pragmatics 33, no. 5 (2001): 653-681.

${ }_{48}$ Abdul Mujib and Jusuf Mudzakir, Nuansa-Nuansa Psikologi Islam (Jakarta: PT RajaGrafindo Persada, 2002). 342
} 
awam. Ikhlas awam ialah ikhlas dalam beribadah kepada Allah karena dilandasi perasaan takut kepada siksa-Nya dan masih mengharapkan pahala dari-Nya. ${ }^{49}$ Namun jika menekankan pada pernyataan salah satu subjek yang menjadi motif perilaku sosialnya adalah "sebaik-baik manusia adalah yang bermanfaat bagi sesamanya", pernyataan subjek tersebut mengindikasikan bahwa tingkat ikhlasnya berada di ikhlas khawas. ${ }^{50} \mathrm{Hal}$ ini senada dengan firman Allah QS. Ali-Imran/3:92 yang mengatakan bahwa bersedekah dengan apa yang kita miliki adalah kebajikan yang sempurna.

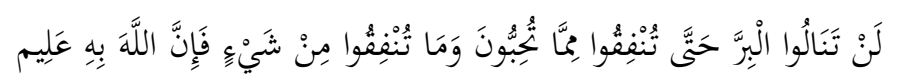

"kamu sekali-kali tidak sampai kepada kebajikan (yang sempurna), sebelum kamu menafkahkan sehahagian harta yang kamu cintai. dan apa saja yang kamu nafkahkan Maka Sesungguhnya Allah mengetahuinya".

Menurut Pearce, Bierhof dan Amato ada empat dimensi situasional perilaku altruisme, yaitu berdasarkan seting sosialnya (terencana \& formal atau spontan \& tidak formal/ planned-formal versus spontaneous-informal), berdasarkan keadaan yang menerima pertolongan (bersifat serius atau tidak serius/ serious versus not serious), berdasarkan jenis pertolongannya (bersifat mengerjakan secara langsung atau tidak langsung/doing-direct versus giving-indirect) dan berdasarkan kedekatan antara penolong dan orang yang ditolong (pribadi atau tanpa identitas/personal versus anonymous). ${ }^{51}$

Berdasarkan data yang tersaji dalam paparan, berdasarkan seting sosialnya, perilaku altruisme ketiga subjek yang bersifat spontaneous-informal terlihat dalam bentuk yang berbeda-beda. Pada subjek satu lebih dominan bersifat spontaneous-informal. Hal ini terlihat dari perilakunya yang menutupi gaji karyawannya yang kurang tidak setiap bulan, tetapi hanya ketika ada kesalahan perhitungan, terjun langsung ke lapangan membantu karyawan yang kesulitan jika ada pekerjaan karyawannya yang terlihat tidak sesuai, berbagi pengalaman dan pengetahuan tentang tes golongan/naik jabatan hanya ketika ada rekan kerja atau mandor yang bertanya. Sedangkan seting sosial yang terencana dari subjek dua terlihat dari setiap jangka waktu tertentu subjek berbagi snack/makanan pada karyawan, mengusahakan karyawan kontrak menjadi karyawan SKU dan merekomendasikan

\footnotetext{
${ }^{49}$ Rosleni Marliany and Asiyah, Psikologi Islam (Bandung: Pustaka Setia, 2015). 176

${ }^{50}$ Ibid. 176

${ }^{51}$ Agus Abdul Rahman, Psikologi Sosial: Integrasi Pengetahuan Wahyu Dan Pengetahuan Empirik. 222-223
} 
karyawan bawahannya yang kompeten untuk naik jabatan. Kondisi sosial yang bersifat spontaneous-informal terlihat ketika subjek bersedia membelikan barang titipan tetangga, mentransfer uang ke bank ataupun mengambilkan paketan tetangga ke kantor pos, memberikan seluruh atau sebagian jatah berasnya untuk karyawan yang tidak mendapat jatah beras, mengajar mengaji anak-anak sekitar dan berbagi lauk dari bekal makannya di Lahan. Sedangkan pada subjek AW, seting sosial yang bersifat spontaneous-informal terlihat dari keceriaan dan jokes (lelucon) diberbagai situasi di lingkungan Afdeling Juliet, menngemudikan mobil untuk mengambil air bersih ke 13 dan kesediaannya dititipi belanjaan, menjadi mediator rekan kerja yang sedang salah paham. Sedangkan dimensi kondisi sosial bersifat terencana terlihat dari ketegasan subjek dalam mengambil kebijakan untuk kebaikan karyawannya.

Berdasarkan keadaan yang menerima pertolongan, mayoritas perilaku altruisme ketiga subjek bersifat serious (serius). Karena yang mereka lakukan memiliki resiko/pengorbanan besar, seperti, pengorbanan waktu, pikiran, tenaga, uang dan kesehatan/fisik. Adapun perilaku yang terlihat tidak serius adalah jokes yang keluar dari diri subjek. Namun secara psikologis hiburan/ keceriaan di lingkungan Afdeling Juliet sangat diperlukan, mengingat kondisi lingkungan yang panas dan media hiburan sangat minim. Hal ini menambah kebersamaan dan keakraban sesama masyarakat Afdeling Juliet.

Berdasarkan jenis pertolongannya, dari data ketiga subjek di atas perilaku altruisme bersifat langsung yaitu perilaku altruisme dilakukan langsung oleh subjek. Mereka selalu terlibat langsung dengan perilaku altruisme yang mereka lakukan.

Menurut Mc. Guire, perilaku altruisme terbagi menjadi empat bentuk, yaitu: casual helping (pertolongan yang sifatnya umum), substantial personal helping (pertolongan yang membutuhkan usaha yang dapat menguntungkan orang lain), emotional helping (pertolongan dengan memberikan dukungan emosional/sosial) dan emergency helping (pertolongan yang bersifat darurat)..$^{52}$

Dari paparan data yang ada, perilaku altruisme yang bersifat casual helping (umum) terlihat dari perilaku berbagi snack/makanan ringan, berbagi lauk dari bekal makannya pada karyawan bawahannya dan selalu menghidupkan suasana lingkungan saat sedang berkumpul bersama rekan kerja dan karyawan-karyawannya. Adapun perilaku altruisme

${ }^{52}$ Ibid. 222-223 
yang membutuhkan usaha/substantional personal helping terlihat dari perilaku mengusahakan perubahan status karyawannya yang tadinya kontrak menjadi karyawan SKU, mengusahakan keluarnya gaji karyawan yang kurang dengan melapor pada pihak atasan, menutupi kekurangan gaji karyawan, memberikan sebagian atau seluruh jatah berasnya pada karyawan yang tidak mendapat jatah beras, setiap malam mengajar mengaji anak-anak di lingkungan Afdeling Juliet, bersedia mengemudikan mobil saat mengambil air bersih ke 13. Sedangkan perilaku altruisme yang berupa dukungan emosi/emotional helping terlihat dari kesediaan ketiga subjek untuk mendengarkan keluhan karyawan bawahan mereka masingmasing, mengajar mengaji anak-anak lingkungan Afdeling Juliet dan selalu mendengarkan rekan kerjanya yang curhat mengenai masalah pribadinya. Menurut Ibnu Qayyim, perilaku altruisme ketiga subjek termasuk dermawan dengan harta, kesenangan, ketenangan dan istirahatnya, hal ini karena ketiga subjek mengabaikan waktu istirahatnya untuk bersusah payah demi kemaslahatan orang lain.

Sarlito W. Sarwono dan Eko A. Mienarno menyebutkan faktor-faktor yang mempengaruhi seseorang berperilaku altruisme terbagi menjadi dua, yaitu faktor situasional (dari luar diri) dan faktor dari dalam diri subjek. Faktor-faktor situasional seperti effect bystander (kehadiran orang lain), daya tarik, atribusi terhadap korban, ada model, desakan waktu dan sifat kebutuhan korban. Sedangkan faktor dari dalam diri seperti mood (suasana hati), sifat, kesamaan, pola asuh, expectation (harapan), gender dan kepercayaan religius. ${ }^{53}$

Tabel 3

Faktor-Faktor Yang Mempengaruhi Perilaku Altruisme Karyawan PT.Tribuana Mas

\begin{tabular}{|c|c|c|c|c|c|}
\hline $\begin{array}{l}\mathbf{N} \\
\mathbf{0}\end{array}$ & \multicolumn{2}{|c|}{$\begin{array}{c}\text { Faktor-faktor pendorong } \\
\text { altruism }\end{array}$} & Subjek I (AB) & Subjek II (PA) & Subjek III (AW) \\
\hline \multirow[t]{6}{*}{1} & Situasio & Efek bystander & - & - & - \\
\hline & nal & Daya tarik & $\sqrt{ }$ & $\sqrt{ }$ & $\sqrt{ }$ \\
\hline & & $\begin{array}{l}\text { Atribusi terhadap } \\
\text { korban }\end{array}$ & $\sqrt{ }$ & $\sqrt{ }$ & $\sqrt{ }$ \\
\hline & & Model (modeling) & - & $\sqrt{ }$ & - \\
\hline & & Desakan waktu & $\sqrt{ }$ & $\sqrt{ }$ & $\sqrt{ }$ \\
\hline & & $\begin{array}{l}\text { Sifat kebutuhan } \\
\text { korban }\end{array}$ & $\sqrt{ }$ & $\sqrt{ }$ & $\sqrt{ }$ \\
\hline
\end{tabular}

${ }^{53}$ Sarlito W. Sarwono and Eko A. Meinarno, Psikologi Sosial. 132 
2

Dalam Mood (suasana

diri hati)

Sifat

Empati

Just world

Tanggung jawab

sosial

Internal locus of

control

Egosentris rendah

Kesamaan

Pola asuh

Harapan

(expectation)

Kepercayaan

religious

1. Faktor situasional (dari luar diri)

Berdasarkan data yang diperoleh dari ketiga subjek, faktor situasional berupa atribusi subjek terhadap korban (karyawan bawahannya) sangat dominan. Hal ini sesuai dengan pernyataan subjek bahwa tidak seharusnya gaji karyawannya kurang. Kesalahan itu bukan dari pihak karyawan bawahannya, sehingga subjek bertanggung jawab untuk membantu karyawannya. Dilihat dari sifat kebutuhan korban, gaji karyawannya sangat penting untuk menopang semua kebutuhan hidup yang bersifat materi, di sisi lain desakan waktu juga sangat mempengaruhi subjek dalam berperilaku altruisme. Hal ini terlihat dari tindakan subjek turun langsung membantu karyawannya yang masih belum paham instruksi teknikteknik mengerjakan tugas di lapangan. Setiap hari seluruh hasil kerja karyawan Afdeling Juliet di cek oleh Mandor 1 dan Asisten, sehingga jika terjadi kesalahan, maka posisi karyawan tersebut tidak aman, bahkan dapat dipecat/berhentikan secara sepihak oleh pihak atasan. Pada subjek lain, situasional yang mempengaruhi perilaku altruisme ialah adanya daya tarik dari perilaku subjek ketika berbagi lauk bekal makanan yang dimakan bersamasama karyawan bawahannya di Lahan. Subjek mengaku senang makan bersama-sama di lahan karena saling memberi itu indah. Subjek juga mengasumsikan bahwa ketidakberuntungan karyawannya yang mendapat jatah beras tidak sesuai atau bahkan tidak mendapat jatah beras sama sekali di luar kendali karyawannya, hal itu karena ada 
oknum yang tidak jujur (atribusi terhadap korban). Subjek juga memiliki model dalam berperilaku altruisme, salah satunya adalah mertuanya. Faktor lain yang juga terlihat adalah desakan waktu dan sifat kebutuhannya urgen. Beras adalah bahan pokok para karyawan yang ada di Afdeling Juliet, sehingga jika mereka tidak mendapatkan jatah beras, maka mereka akan kesulitan makan. Hal ini disebabkan akses jalan menuju pasar kota atau pedesaan sangat jauh. Harga sembako yang ada di 13 sangat mahal dan tidak boleh hutang, sehingga menjadi pertimbangan tersendiri bagi subjek untuk berbagi.

Sedangkan faktor-faktor situasional yang terlihat dari data subjek lainnya adalah desakan waktu dan sifat kebutuhan korban. Bagi masyarakat Afdeling Juliet, air bersih merupakan sumber kehidupan dan kesehatan yang utama. Air yang ada di sungai depan mes mereka sangat masam, sehingga subjek tidak keberatan meskipun malam hari ke 13 untuk mengambil air bersih. Subjek juga menilai kehidupan di Afdeling Juliet sangat unik dan menarik (daya tarik), kepribadiannya yang supel, periang dan tergolong masih muda membuat ia merasa tertarik mencari pengalaman hidup di sana dan menolong siapa saja yang ia mampu.

\section{Faktor dari dalam diri}

Berdasarkan paparan data di atas, faktor-faktor dari dalam diri ketiga subjek dalam berperilaku altruisme terlihat dalam bentuk yang berbeda. Pada umumnya seseorang yang sedang memiliki mood yang baik akan lebih cenderung menampilkan perilaku prososial ataupun altruisme. Akan tetapi sebuah emosi positif dapat mengurangi kemungkinan untuk merespon dalam memutuskan berperilaku altruisme ataupun sebaliknya. Dilihat dari faktor mood (suasana hati), perilaku altruisme subjek terlihat pada saat suasana hati sedang sedih (prihatin) maupun good mood (suasana hati senang), seperti ketika adanya rasa kasihan pada karyawannya yang mendapat gaji tidak sesuai, melihat cara kerja karyawannya tidak sesuai prosedur, prihatin melihat ketidak adilan yang terjadi dan kondisi pendidikan anak-anak yang kurang layak. Pada saat mood baik (suasana hati senang), subjek juga berperilaku altruisme, seperti berbagi snack/makanan ringan, berbagi pengetahuan/ sharing tentang penguasaan lahan dan berbagi pengalaman tentang tes naik golongan atau jabatan.

Beberapa penelitian membuktikan bahwa terdapat hubungan antara karakteristik (sifat) seseorang dengan kecendeungan untuk berperilaku altruisme. Menurut Karremans, 
sifat forgiveness (pemaaf) mempunyai kecenderungan mudah menolong. Dari data di atas, subjek satu termasuk orang pemaaf dan sabar. Hal ini terlihat dari pernyataan subjek ketika ia berhadapan dengan rekan kerja yang menentang instruksi dan rekan kerja yang bersikap tidak baik terhadap subjek. Pada subjek dua, sifat pemaaf tidak terlihat jelas, namun dari pernyataan subjek yang lebih memilih cuek terhadap perkataan atau cemoohan rekan kerja atau tetangga yang tidak baik terhadapnya kemudian subjek mengembalikan baik buruknya pada Allah, maka mengindikasikan bahwa subjek juga pemaaf.

Dalam analisis peneliti, ketiga subjek memiliki rasa empati yang kuat melihat keadaan lingkungan sekitarnya. Hal ini sesuai dengan teori hipotesis empathy-altruisme bahwa mekanisme utama terbentukanya perilaku altruisme adalah adanya reaksi emosi positif terhadap masalah orang lain. Dengan menyaksikan orang lain yang sedang kesulitan (empathic concern) akan menghasilkan motivasi altruistik (altruistic motivation) untuk mengurangi kekhawatiran orang lain (other person's distress) sehingga pada akhirnya subjek memutuskan untuk bertindak altruis. ${ }^{54}$ Subjek merasa iba melihat ketidak adilan yang terjadi pada karyawannya, tidak ingin karyawannya terzolimi dan memahami perasaan rekan kerjanya yang curhat (curahan hati/berkeluh kesah).

Perilaku altruisme ketiga subjek berkaitan dengan internal locus of control (kontrol diri) yang dimiliki subjek. Subjek memiliki kepercayaan bahwa perilaku mereka adalah sematamata untuk meminimalisir hasil yang buruk dan memaksimalkan hasil yang baik. Sebagaimana pernyataan mereka yang menginginkan kesejahteraan bagi karyawan bawahannya.

Rasa tanggungjawab sosial dimiliki oleh ketiga subjek. Hal ini terlihat dari kesadaran mereka sebagai mandor (komando/pemimpin) karyawannya. Hal ini senada dengan teori sosial-kognitif dari terbentunya perilaku altruisme, yaitu berawal dari perhatian ketiga subjek terhadap kondisi/sesuatu yang salah, kemudian ketiga subjek menginterpretasikan bahwa sesuatu yang salah itu membutuhkan pertolongan dan akhirnya muncul rasa tanggung jawab pada diri ketiga subjek untuk bertindak altruisme. Hal ini juga selaras dengan teori norma sosial bahwa salah satu pedoman untuk melakukan pertolongan adalah responsibility norm (norma tanggung jawab sosial). ${ }^{55}$

\footnotetext{
54 Taufik, Empati: Pendekatan Psikologi Sosial. 138

${ }^{55}$ Agus Abdul Rahman, Psikologi Sosial: Integrasi Pengetahuan Wahyu Dan Pengetahuan Empirik. 225
} 
Berbeda dengan rasa tanggungjawab sosial, ketiga subjek sama-sama memiliki egosentrisme yang rendah. Rendahnya egosentris subjek terlihat dari kesediaannya mengganti sebagian uang gaji karyawan yang kurang. Padahal kesalahan administrasi itu bukan kesalahan subjek, bisa saja uang subjek ditabung untuk mewujudkan keinginan subjek memiliki rumah sendiri. Subjek juga tidak perlu berbagi informasi dan pengalaman tentang tes golongan, karena pada dasarnya semua mandor sudah dibekali buku untuk dipelajari masing-masing dan setiap mandor bagian telah di training sebelumnya selama tiga bulan. Lebih baik waktu luang subjek digunakan untuk istirahat, namun kenyataannya subjek selalu meluangkan waktu untuk berbagi ilmu dan pengalaman kerja.

Hal lain juga terlihat dari kesediaan subjek untuk mengajar ngaji anak-anak. Padahal setelah kerja seharian, kemudian meeting dan menyusun laporan kerja (LPK), malam adalah waktu yang tepat untuk istirahat, terlebih lagi subjek memiliki anak yang masih bayi $( \pm 10$ bulan). Namun subjek mengalahkan ego/ kepentingan pribadinya ketika ia menyadari kondisi anak-anak yang pendidikannya kurang memadai. Selain itu, kesiap siagaan subjek bersama beberapa temannya untuk menyediakan air bersih bagi masyarakat yang memerlukan pengorbanan tenaga, karena subjek dan beberapa teman harus mengangkat beberapa jeriken bervolume 20 liter dari kran gentong penampungan air ke bak strada (mobil).

Ketiga subjek sama-sama memiliki pandangan bahwa keseimbangan dan keadilan harus tetap dijaga. Hal ini terlihat dari usaha mereka dalam menyeimbangkan antara hak dan kewajiban karyawan bawahannya. Hal ini senada dengan teori evolusi yang salah satu pertimbangannya dalam menjaga keseimbangan adalah adanya prioritas ketika menolong. Orang cenderung berperilaku altruisme ketika adanya rasa kesamaan dan penolong merasa mampu untuk menolong orang yang lebih lemah. Subjek melakukan tindakan altruisme seperti berbagi snack, memberikan sedikit uang pada karyawannya yang sedang mengalami musibah, terjun langsung ke lapangan untuk membimbing karyawan yang tidak paham instruksi dan berbagi ilmu dan pengalaman tentang tes naik jabatan/golongan karena ia merasa mampu dan memiliki potensi tersebuthal ini karena menurutnya tindakannya bisa meningkatkan kesejahteraan orang yang ditolongnya. Subjek memberi feedback (cerminan) pada dirinya bahwa sangat tidak nyaman ketika ia berada di posisi sulit, sehingga ia berusaha agar karyawannya tidak mengalami permasalahan yang fatal. 
Selain itu, memberikan sebagian atau seluruh jatah berasnya pada karyawannya, mengajar ngaji anak-anak dan berbagi lauk makan berawal dari adanya rasa kesamaan dalam dari subjek. Kesamaan ini terlihat dari pengalamannya di beberapa tempat kerja bahwa pendidikan anak para karyawan sawit terutama dari segi agama tidak diperhatikan orang tuanya dengan baik. Di perusahaan tidak ada TPA (taman Pendidikan al-Qur'an) atau guru agama khusus yang mengajari anak-anak mereka perihal agama. Selain itu subjek memiliki prinsip bahwa sesama perantau, tetangga adalah saudara. Di sisi lain, bagi subjek ketiga, tujuan subjek dan karyawan bawahannya adalah sama, yaitu prestasi kerja dan kesejahteraan. Hal ini selaras dengan pendapat Miller bahwa kita akan lebih berempati dan cenderung membantu mereka yang sama dengan kita (bisa tampilan fisik maupun kepercayaan) ${ }^{56}$

Menurut Frank Emerson, agama adalah pusat dari kedermawanan (altruisme dalam sudut pandang Islam). Kepercayaan religius memprediksikan altruisme jangka panjang, sebagaimana yang direfleksikan kegiatan sukarela dan kontribusi amal. ${ }^{57}$ Dalam Islam, altruisme dapat mencerminkan keimanan seseorang. Semakin besar keimanan seseorang pada Tuhannya, maka akan semakin besar pula kemungkinan orang tersebut berperilaku altruisme. Hal ini terlihat berdasarkan data tentang altruisme yang diperoleh dari dua subjek lebih banyak dibandingkan subjek ketiga.

Dalam sudut pandang Islam, perilaku altruisme ada kesamaan dengan ikhlas karena dari data ketiga subjek merasa perbuatan yang ia lakukan baik dan tidak ada paksaan dari pihak luar yang memaksa mereka berperilaku altruisme, sebagaimana pendapat Goddard bahwa ikhlas akan muncul pada diri orang yang beramal diantaranya ketika orang yang beramal tersebut ingin melakukannya dan pelaku berfikir bahwa perbuatan itu baik. ${ }^{58}$ Alasan subjek berperilaku altruisme adalah keyakinannya bahwa Allah akan mengganti amalnya dengan kemudahan dan rezeki yang lebih banyak selain pahala yang sudah menjadi ganjaran tetap dan ingin menjadi orang baik yang bermanfaat bagi sesamanya sebagaimana yang anjuran Rasulullah. Cara mereka berperilaku altruisme juga tidak

\footnotetext{
${ }^{56}$ David G Myer, Psikologi Sosial. 220

57 Ibid. 229

${ }^{58}$ Goddard, "Sabar, Ikhlas, Setia - patient, Sincere, Loyal? Contrastive Semantics of Some 'virtues' in Malay and English." 668
} 
menyinggung perasaan penerima kebaikan mereka, hal ini terlihat dari pernyataan informan bahwa ia merasa senang dengan bantuan yang diberikan subjek. Hal ini sebagaimana firman Allah QS. al-Baqarah/2: 264

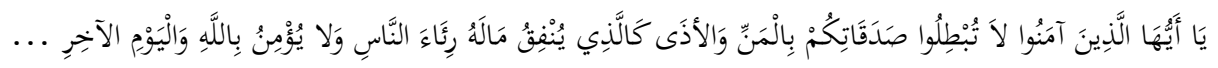

"Hai orang-orang yang beriman, janganlah kamu menghilangkan (pahala) sedekahmu dengan menyebut-nyebutnya dan menyakiti (perasaan si penerima), seperti orang yang menafkahkan hartanya karena riya kepada manusia dan Dia tidak beriman kepada Allah dan hari kemudian..."

Ayat tersebut menunjukan bahwa perilaku menolong hendaknya dilakukan dengan cara-cara yang baik, jangan sampai menyakiti atau merendahkan orang yang ditolongnya.

Perilaku altruisme yang dilakukan oleh ketiga subjek menurut Ibnu Qayyim merupakan kedermawanan, baik dermawan dengan ilmu, dermawan kekuasaan, dermawan dengan kesenangannya, dermawan dengan kesabaran dan menahan diri. ${ }^{59}$ Perilaku altruisme ketiga subjek sesuai dengan sabda rasulullah yang dituturkan Abu Hurairah ra:

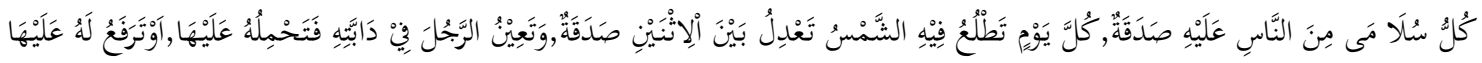

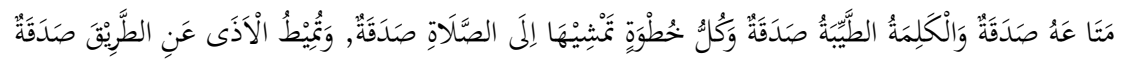

"Setiap persendian manusia, selama matahari itu masih terbit harus diberi sedekah. Mendamaikan dua orang yang sedang bersengketa adalah sedekah. Membantu seseorang mengangkatkan atau menaikan barangnya ke atas kendaraan adalah sedekah. Ucapan yang baik adalah sedekah. Setiap langkah menuju sholat adalah sedekah. Menyingkirkan gangguan yang berada di tengah jalan pun merupakan sedekah".

Hadis ini menjelaskan bahwa sedekah dilakukan dengan berbagai bentuk, seperti membantu mengangkatkan barang orang yang kita lihat, berbagi dengan harta yang kita miliki, mendamaikan orang yang sedang berselisih, tutur kata yang baik ataupun menyingkirkan gangguan yang ada di tengah jalan.

Dalam pandangan psikologi Islam, perilaku altruisme yang dilakukan salah satu subjek agak berbeda dari yang dua. subjek bersikap tegas pada karyawannya agar mereka mendapat prestasi kerja yang baik. Hal ini sangat wajar, karena berdasarkan paparan data, meskipun orang tua subjek memiliki wawasan agama yang baik, akan tetapi ia tumbuh dan besar bersama Om-nya yang berlatar belakang lebih rasional. Hal inilah alasan kenapa subjek tidak sering mengaitkan urusan kerja dengan agama. Ditambah subjek baru berusia 19 tahun, hal ini mengindikasikan bahwa ia masih tergolong remaja yang salah satu tugas

${ }^{59}$ Al-Jauziyah, Madarijus Salikin (Pendakian Menuju Allah), Penjabaran Kongkrit Iyyaka Na'budu Wa Iyyaka Nasta'in, Terj. 251-252 
perkembangannya adalah mencari identitas diri dan perkemangan spiritualnya belum terlihat.

Berdasarkan faktor expectation (harapan), ketiga subjek sama-sama memiliki harapan. Hanya saja harapan kesejahteraan bersama subjek tiga (subjek dan karyawan bawahannya) terlihat pada aspek yang berbeda, yaitu harapannya untuk mendapat prestasi yang terbaik dalam bekerja karena ada bonus akhir tahun yang menjadi target. Sedangkan harapan kedua subjek lain adalah semata-mata untuk kesejahteraan karyawannya dan mengharap balasan pahala serta kemudahan hidup dari Allah karena hal ini sesuai dengan sabda Rasulullah:

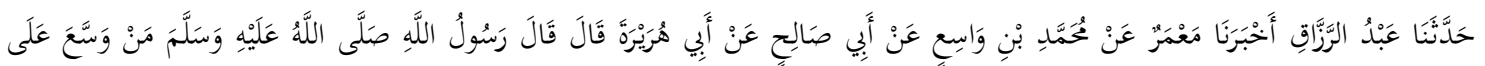

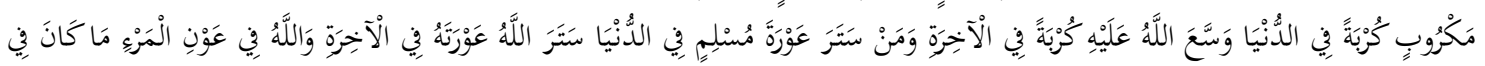

$$
\begin{aligned}
& \text { عَوْنِ أَخِيِيه }
\end{aligned}
$$

“Telah menceritakan kepada kami Abdurrazzaq telah mengabarkan kepada kami Ma'mar dari Muhammad bin Wasi' dari Abu Shalih dari Abu Hurairah, dia berkata; Rasulullah Shallallahu 'alaihi wa Salam bersabda: "Barangsiapa melapangkan kesulitan orang yang diterpa kesulitan di dunia maka Allah akan melapangkan kesulitannya kelak di hari kiamat, dan barangsiapa menutupi aib seorang muslim di dunia maka Allah akan menutupi aibnya kelak di hari kiamat, dan Allah selalu menolong hamba-Nya selama hamba-Nya menolong saudaranya."

Faktor expectation (harapan) juga senada dengan teori pertukaran sosial bahwa tindakan seseorang dilakukan berdasarkan pertimbangan untung-rugi. Namun pada perilaku altruisme keuntungan yang diharapkan tidak berasal dari sesama manusia atau orang yang ditolong, tetapi harapan bersandar pada Tuhan seperti yang diharapkan oleh dua subjek. Adanya reward pahala atau punishment penyesalan ketika seseorang memutuskan untuk menolonga atau tidak, senada dengan teori behaviourisme-altruisme. Perilaku altruisme dapat dijelaskan dalam perspektif belajar sosial (social learning). B.F. Skinner beranggapan bahwa kita cenderung mengulangi atau memperkuat perilaku yang memiliki konsekuensi positif bagi diri kita. ${ }^{60}$ Reward berupa pahala dan rahamat/berkah hidup merupakan konsekuensi positif untuk orang-orang beriman yang beramal dengan ikhlas, sebagaimana firman Allah QS. al-A'raf/7: 56 .

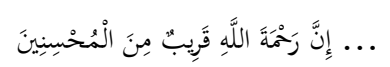

".. Sesungguhnya rahmat Allah Amat dekat kepada orang-orang yang berbuat baik".

\footnotetext{
${ }^{60}$ Feldman, R. S, Pengantar Psikolog, vol. 2, p. .228
} 
Pada dasarnya harapan berasal dari berbagai sumber, antara lain pengalaman masa lalu, informasi dari orang lain dan stereotype. Terkadang harapan menjadi self-fulfilling prophecies, suatu situasi dimana harapan kita tentang orang lain tidak hanya membentuk perilaku sendiri, tetapi juga menyebabkan orang tersebut untuk berperilaku dengan caracara yang mengonfirmasi kepercayaan awal kita tentangnya. ${ }^{61}$ Harapan subjek untuk kesejahteraan karyawannya berdasarkan teori tersebut bersumber dari pengalaman masa lalu, yaitu pengalaman subjek mulai merintis kerja dari bawah sampai menjadi mandor 1 . Harapan subjek lain untuk kesejahteraan orang di sekitar lingkungannya bersuber dari pengamatan dan pengalaman yang pernah dialaminya. Sedangkan sumber harapan subjek lainnya adalah adanya stereotype dan informasi yang diperoleh subjek mengenai sistem kerja yang ada di PT.TBM. Stereotype yang ada subjek buktikan dengan observasinya pada bulan pertama turun kerja di Afdeling Juliet.

Latar belakang keluarga ketiga subjek adalah keluarga yang berpendidikan dan asertif. Keluarga subjek satu selalu menasehatinya agar berperilaku sesuai norma dan ajaran agama, bekerja jujur dan seimbang antara hak dan kewajiban. Keluarga subjek dua sangat mengutamakan pendidikan anaknya. Hal ini terlihat dari pernyataan subjek bahwa ibu subjek selalu memotivasi subjek untuk rajin sekolah dan mengaji. Mertua subjek juga tergolong orang yang dermawan. Hal ini senada dengan teori behaviourisme-altruisme bahwa salah satu faktor yang membentuk perilaku altruisme adalah modeling (ada model yang menjadi panutan).

Dalam pandangan humanistik, katiga subjak memiliki sebagian besar kriteria aktualisasi diri. Ketiga subjek memiliki persepsi yang efesien tentang realitas, mereka menilai situasi secara akurat dan jujur serta memperhatikan ketidak adilan dan katidak jujran. Hal ini terlihat adanya oknum-oknum yang berbuat curang dan tidak menyampaikan hak karyawan lain.

Ditinjau dari segi penerimaan diri, ketiga subjek memiliki penerimaan diri yang baik, baik penerimaan diri sendiri, orang lain ataupun lingkungan. Hal ini terlihat dari hasil observasi dan wawancara bahwa ketiga subjek tidak pernah ada permasalahan yang berarti selama mereka tinggal dan bertetangga di Afdeling Juliet.

${ }^{61}$ Elis Anisah Fitriah, Psikologi Sosial Terapan. 12 
Menurut aliran humanistik, kriteria orang yang memiliki aktualisasi diri adalah orang yang mempunyai spontanitas yang baik. Dari ketiga subjek, subjek ketiga memiliki spontanitas yang paling baik. Hal ini terlihat dari keberanian dan ketegasan subjek ketika berhadapan dengan atasan maupun bawahannya. Ia juga memiliki selera humor yang tinggi dan supel dalam pergaulan. Sedangkan kedua subjek lain lebih tertata dan kalem dalam berinteraksi.

Orientasi kerja atau tugas yang konkrit harus dimiliki seseorang ketika seseorang akan mencapai aktualisasi diri. Ketiga subjek memiliki orientasi tugas yang baik, memiliki misi dan tujuan yang jelas. Selain itu, ketiga subjek juga memiliki hubungan interpersonal yang mendalam dan ketertarikan kemanusiaan yang positif.

\section{Kesimpulan}

Berdasarkan data penelitian yang telah diperoleh, dapat diitarik kesimpulan bahwa Perilaku altruisme dengan pendekatan Islamnya berupa konsep ikhlas, perilaku karyawan di PT.Tribuana Mas (TBM) Afdeling Juliet mencakup komponen altruisme. Komponen altruisme yang dilakukan ketiga karyawan sebagian besar sama, yaitu perilaku helping (menolong), mempertimbangkan hak dan kesejahteraan orang lain, sharing (berbagi) dan honesty (kejujuran). Perilaku donating \& generosity hanya terlihat ada pada subjek 1 dan 2. Sedangkan perilaku Cooperation (kerja sama) terlihat hanya tergambar pada subjek 3. Perilaku altruisme karyawan juga sesuai dengan ajaran Islam, yaitu beramal dengan pondasi ilahiyah (ikhlas). Namun, pada subjek AW altruisme yang dilakukan masih bernuansa kemanusiaan.

Adapun faktor yang mendorong ketiga karyawan berperilaku altruisme di PT.Tribuana Mas (TBM) Afdeling Juliet secara situasional (faktor dari luar diri), ketiga subjek terdorong oleh adanya daya tarik, atribusi terhadap korban, desakan waktu, sifat kebutuhan korban, ketiga subjek tidak ada yang terpengaruh oleh efek bystander dan faktor modeling hanya terlihat pada subjek PA saja. adapun berdasarkan faktor dari dalam diri, Ketiga subjek memiliki sifat karakteristik prilaku altruism, seperti sifat empati, just world, tanggung jawab sosial, Internal Locus of Control, dan egosentris lemah. Ketiga subjek juga memiliki prinsip kesamaan dan pengharapan yang positif. Berdasarkan faktor mood, subjek 1 dan 2 berperilaku altruisme pada saat mood sedih maupun senang, sedangkan mood subjek 2 
terlihat selalu ceria (selalu memperlihatkan mood baik). Berdasarkan faktor kepercayaan religius, motivasi subjek 1 dan 2 untuk berperilaku altruisme adalah keyakinannya mengamalkan ajaran agama dan ingin menjadi sebaik-baik manusia. Sedangkan pada subjek 3 faktor kepercayaan religius tidak terlihat.

\section{Saran}

Bagi para mandor perkebunan sawit PT.Tribuana Mas (TBM) Afdeling Juliet agar selalu peduli dengan keadaan lingkungan sekitarnya dan memperhatikan kesejahteraan karyawan bawahannya dengan bijak agar selalu menjadi tim kerja yang solid dengan landasan bekerja dan beramal sesuai syari'at agama serta bisa menjaga komitmen sesuai perjanjian kontrak kerja untuk bekerja dengan baik dan tidak berbuat curang bahkan mengambil hak karyawan lain. Bekerja dengan baik sesuai norma, baik norma perusahaan, norma sosial, terlebih lagi norma agama agar hasil kerja mengandung berkah dan bernilai ibadah. Adapun bagi jajaran staf atasan PT. Tribuana Mas (TBM) agar cepat bertindak ketika ada pengaduan permasalahan yang terjadi di lapangan dan mengontrol secara detail distribusi sarana dan prasarana yang dibagikan ke lapangan seperti membentuk tim khusus agar kesejahteraan yang diinginkan pihak perusahaan sampai pada target.

Penulis menyadari meskipun penelitian ini telah semaksimal mungkin dilaksanakan, namun tidak menutup kemungkinan masih jauh dari kata sempurna dan banyak kekurangan. Oleh karena itu, diharapkan pada peneliti selanjutnya dapat meneliti objek ini (Perilaku altruisme) dengan pendekatan Psikologi Islam yang lain.

\section{Kepustakaan}

Abdul Mujib, and Jusuf $\quad$ Mudzakir. Nuansa-Nuansa Psikologi Islam. Jakarta: PT RajaGrafindo Persada, 2002.

Agus Abdul Rahman. Psikologi Sosial: Integrasi Pengetahuan Wahyu Dan Pengetahuan Empirik. Jakarta: RajaGrafindo Persada, 2013.

Aliah B. Purwakania Hasan. Psikologi Perkembangan Islami: Menyingkap Rentang Kehidupan Manusia Dari Kelahiran Hingga Pascakematian. Jakarta: RajaGrafindo Persada, 2006.

Al-Jauziyah, Ibnu Qayyim. Madarijus Salikin (Pendakian Menuju Allah), Penjabaran Kongkrit Iyyaka Na'budu Wa Iyyaka Nasta'in, Terj. Jakarta: Pustaka Al-Kautar, 2005. 
Al-Qalami, Abu Fajar. Ringkasan Ihya'Ulumiddin, 2003.

Amin, Syukri. Tasawuf Kontekstual Solusi Problem Manusia Modern. Yogyakarta: Pustaka Pelajar, 2003.

Anidal Hasjir. Kamus Istilah Psikologi. Jakarta: Progress, 2003.

David G Myer. Psikologi Sosial. Jakarta: Salemba Humanika, 2012.

Desmita. Psikologi Perkembangan. Bandung: Remaja Rosdakarya, 2013.

Dinas Perkebunan Prov Kalsel. “Statistik Disbun Provinsi Kalimantan Selatan.” Accessed March 2, 2015. http://disbun.kalselprov.go.id.

Elis Anisah Fitriah. Psikologi Sosial Terapan. Bandung: Remaja Rosdakarya, 2014.

Feldman, R. S. Pengantar Psikolog. 10th ed. Vol. 2. Jakarta: Salemba Humanika, 2012.

Fuad Nashori. Psikologi Sosial Islami. Jakarta: PT. Refika Aditama, 2008.

Goddard, Cliff. "Sabar, Ikhlas, Setia - patient, Sincere, Loyal? Contrastive Semantics of Some 'virtues' in Malay and English." Journal of Pragmatics 33, no. 5 (2001): 653-681.

Henry Hazlitt. Dasar-Dasar Moralitas. Yogyakarta: Pustka Pelajar, 2003.

Ibnu Hajar Al-Asqalani, and Al Imam Al-Hafizah. Fathul Baari Syarah: Shahih Bukhari. Jakarta: Pustaka Azzam, 2008.

Jalaluddin. Psikologi Agama. Jakarta: RajaGrafindo Persada, 1998.

Lura L King. Psikologi Umum: Sebuah Pandangan Apresiatif. Jakarta: Salemba Humanika, 2010. Lynn Wilcox. Psikologi Kepribadian: Analisis Seluk Beluk Kepribadian Manusia. Jogjakarta: IRCISoD, 2012.

Martin Seligman. Beyond Autentic Happiness: Menciptakan Kebahagiaan Paripurna Dengan Psikologi Positif. Bandung: Kaifa, 2013.

MIF Baihaqi. Psikologi Pertumbuhan: Kepribadian Sehat Untuk Mengembangkan Optimisme. Bandung: Remaja Rosdakarya, 2008.

Muhammad Tholhah Hasan. Islam Dalam Perspektif Sosio Kultural. Jakarta: Lentabora Press, 2005.

Pandji Anggora. Psikologi Kerja. Jakarta: Rineka Cipta, 2009.

Robert A. Baron, and Byrne Donn. Psikologi Sosial Jilid 1. Jakarta: PT Gelora Aksara Pratama, 2004. 
Robert Stephen Feldman. Social Psychology: Theories, Research and Aplications. New York: McGRAW-HILL Book Company, 1985.

Rosleni Marliany, and Asiyah. Psikologi Islam. Bandung: Pustaka Setia, 2015.

Sarlito W. Sarwono, and Eko A. Meinarno. Psikologi Sosial. Jakarta: Salemba Humanika, 2009.

Sudarsono. Kamus Filsafat Dan Psikologi. Jakarta: Rineka Cipta, 1993.

Sunyoto Usman. Pembangunan Dan Pemberdayaan Masyarakat. Yogyakarta: Pustaka Pelajar, 2008.

Syahrial Yusuf. Spiritual Enterpreneurship Quotien: Kiat Menjadi Pengusaha Dunia Bahagia, Akhirat Surga. Jakarta: Lentera Ilmu Cendikia, 2010.

Taufik. Empati: Pendekatan Psikologi Sosial. Jakarta: RajaGrafindo Persada, 2012.

Tri Dayakisini, and Hudainiah. Psikologi Sosial. Malang: UMM Press, 2008. 